\title{
The Relationship between Applying Methods of Accounting Information Systems and the Production Activities
}

\author{
Ali Mahmoud Alrabei ${ }^{1}$, Ayman Ahmad Abu Haija ${ }^{1} \&$ Laith Abdallah Aryan ${ }^{2}$ \\ ${ }^{1}$ Department of Accounting, Faculty of Economic and Business, Jadara University, Jordan \\ ${ }^{2}$ Department of Accounting, Faculty of Economic and Business, Ajloun University, Jordan \\ Correspondence: Ali Mahmoud Alrabei, Department of Accounting, Faculty of Economic and Business, Jadara \\ University, Jordan. Tel: 962-7-9848-4381. E-mail: alialrabei@yahoo.com
}

Received: January 20, 2014

Accepted: February 19, 2014

Online Published: April 25, 2014

doi:10.5539/ijef.v6n5p112

URL: http://dx.doi.org/10.5539/ijef.v6n5p112

\begin{abstract}
Accounting information system plays a significant role in enhancing companies environment, thus it is necessary that companies stress on the application of AIS to optimize their business. This study testes the relationship between AIS and production activities (i.e., production design, production planning and control, production operation and cost accounting).This study tests the head of departments' perception towards the relationship between applying accounting information systems and production activities, out of 113 questionnaires distributed, only 69 questionnaires were returned and valid to run the analysis yielded $61 \%$ responses rate. The results show a positive significant relationship between AIS and production activities (i.e., production design, production planning and control, production operation and cost accounting).This study recommends that the company have to concentrate on the application of accounting information system to benefit from its merits in all production activities. It will be helpful in future to explore the difficulties that face the Jordanian companies in applying accounting information system in production design.
\end{abstract}

Keywords: Accounting Information System (AIS), production activities, Jordanian companies

\section{Introduction}

Accounting information system is one of the basic things that a business must think about. Karthikeyan, (2010) defines accounting information system as the data and information which flow through an information system come from many sources: firstly, business activities with individuals or organizations external to the business, such as sales, purchases, payments of cash, or receipts of cash; secondly, internal business activities, such as placing raw materials in to process, using direct labor, and transfers; thirdly, the feedback resulting from output information and managerial decisions. Without an ample accounting information system, every company would locate themselves in anarchy. The importance of accounting system in organizational policies and models is one of the principal success factors that effectively support the achievement of accounting and financial objectives.

The accounting Information System (AIS) is a computer based system of records, which amalgamate accounting principles and concepts which is used to examine and record business transaction for the purpose to prepare financial statement and provide accounting data to the users. An adequate accounting information system helps to make their accounting activities more easily , quickly and more accurately as accounting records are examined and financial statements are prepared within the system which allows to save time of employees, eschew mistakes and provides information about financial position of the company .Every company can get benefit from an accounting software package. Accounting software helps in improving the way critical financial-related processes are managed across the business which results in increasing the efficiency and smoother execution of core business operations. It can also assist companies in avoiding the risks and severe penalties related with non-compliance with financial reporting laws and guidelines.

The developments in accounting information technologies, together with globalization, have produced such concepts as "new economy", "e-commerce" and "new accounting". These developments have helped in saving time and money and also reduced the costs by accelerating transactions and communication. The developments in information systems have caused all or some of the financial transactions in a business to be carried out in such different forms in electronic environments as electronic commerce and electronic data exchange. So, as a 
result, the financial transactions were to be removed from the old-fashioned paper-based activity environment to the electronic environment. Accounting information system is described as the language of a business, and therefore makes change in all processes like, recording, reporting, categorization, and analysis. These changes has also affected some accounting applications i.e., keeping the books, preparing financial statements, tax statements and auditing activities.

These above-mentioned developments and changes in accounting information system, applications and profession inevitable have lead to a change in the demands of the society and the expectations of the members of accounting profession are increasing. The global change in the concept of business administration have forced the members of accounting profession to recognize the economic, social as well as political changes that are being experienced in the world and accumulate knowledge about different cultures, and to be able to look at the events with a global perspective.

Despite the fact that business units have used modern management techniques, which require tremendous change in production methods and machinery, appraisal systems still face severe criticism. In this study, the researchers reviewed related literature on the Accounting Information System in production cycle. Secondly, the Problems of the study are discussed. Then objectives of the study and Research Methodology whichinclude Product Design, Production Planning, Production Operations were analyzed. Then the main hypothesis are formulated which provide statistical information about the sample. Last section discusses the main results and directions for further research are highlighted.

\section{Literature Review}

The Information provided to managers by Aaccounting Information Systems (AISs) are designed for use in various ways. Researchers in accounting mainly concentrate on three characteristics i.e., focus, assessment and time horizon (IMA, 1995). Focus indicates the extent in which data is internally collected and that this signification refers to organization, for example the rate of productivity in occupations, or external focus on factors, which are significant to environment such as economic conditions. Evaluation and measurement are indicative of financial data including interest margin or non-financial data such as the rate of absenteeism explained under non-financial conditions (Mia, 1993). Time horizon normally reflects historical weekly or monthly data or decisive future of data prediction such as the probability of calculation in a forthcoming project. These characteristics can be explained as the basis for the monarchy of AISs. Usually designed AISs retain relationship with internal financial data along with past time horizon in organization. Therefore, in a smaller monarchy AISs only incorporate internal, financial and historical data. In other words, slight excess in internal, financial and historical data and the vast extent of AISs incorporates external, non-financial and future-centred data. The structure of management accounting system is implemented in different accounting studies (Gul \& Chia, 1994; Chong \& Chong, 1997; King \& Ismail, 2005).

Sera feimidis and Simithon, 2003, stated that how to assess the Accounting information systems by studying the social and organizational dimensions affecting them. To achieve the objectives of the study, the questionnaire was designed and applied to a sample of 160 employees working in information systems departments of participating companies. The most important result of this paper is that there are social and organizational dimensions that must be addressed and the valuation process of these systems were complex and it needs large human efforts of the entity's staff who are familiar with the system and know its secretes and capacities. The study indicates that it is necessary that assessment process is synchronously conducted and planned on a regular basis with the work performance.

Morteza and Rafiei (2011).considered production cycle as the heart of manufacturing firms and has special relationship with all internal sections (units) in which other units have duty to satisfy hardware and software needs of production cycle, in order to optimum application. In doing so they tried to assess the effect of internal factors on optimum application of Production cycle. The study recommended to improve the relation between internal units and production cycle, and it is necessary for the firms to update their Accounting Information Systems based on new technologies.

Deshmukh and Ashutosh(2006) stated in their study that production conversion cycle measures a range of activities such as design of products, planning and controlling of production process and cost accounting. Production planning and control involves planning production by optimizing factors such as customers demand, availability of labor and materials, capacity restriction, distribution limits and storage restriction, are to mention a few. Well-Planned manufacturing activities are carried out by processing raw materials though a combination of machines and humans and generate a finished product. The cost accounting system provides information useful for estimating production function, formatting product costs and generating information for inventory 
valuation for external reporting purposes. The twin objectives of quality and cost reduction have been a holy grail for manufacturing industries. The last few decades have observed a number of methodologies, such as material requirements planning (MRP), manufacturing resource planning (MRP II), Just in Time (JIT), Robotics and Six Sigma, which attempted to achieve these objectives. The conversion cycle is most visible in manufacturing organizations; however, the service industry has also benefited from conversion cycle concepts and theories. The conversion cycle interfaces with different functions and departments in the organization, such as purchasing, marketing and finance. Earlier efforts for quality and cost management focused on connecting different departments and streamlining internal operations of organizations.

Al-Hantawi (2001) has specified that the most important characteristics which makes the accounting information systems as effective and efficient, are the accuracy and speed of processing financial data into accounting information, therefore providing management with the necessary accounting information on time; in order to perform functions like planning, control, evaluation, speed and accuracy in retrieving stored overall and descriptive information when it is needed; adequate flexibility; general acceptance of workers; simplicity, and to be associated with other information systems in the entity.

\section{Problem of the Study}

Accounting information system is essential to any organizations long-run success. The production cycle, revenue cycle, expenditure cycle, human resources cycle, all of these cycles send information about plan production level, inventory level; raw materials needs, labor costs and cost of goods manufactured are sent to general ledger and reporting information system, therefore, the managers at various cycles are in need of certain type of accounting information system. And the question that mention here is how the accounting information system impact on production activities.

\section{Objectives of the study}

The study aims to identify how the organizations accounting information system can help production activities to achieve its manufacturing goals with the following objectives:

1- To examine the relationship between the application of accounting information system and production activities in product design.

2- To examine the relationship between the application of accounting information system and production activities in production planning and control.

3- To examine the relationship between the application of accounting information system and production activities in production operations.

4- To examine the relationship between the application of accounting information system and production activities in cost accounting.

\section{Research Methodology}

This study aims to test the head of departments' perception towards the relationship between accounting information system and the production activities, this study used only the head of departments in industrial companies because they are only familiar with aforementioned issues. Questionnaires were sent to head of departments in Al-Hasan Industrial Zone- Irbid, to examine their perception towards the relationship between accounting information system and production activities.

\subsection{Hypotheses of the study}

This study has four hypotheses were developed to test the relationship between AIS and production activities as follows:

H1: There is a relationship between Accounting Information System and production activities in product design.

H2: There is a relationship between Accounting Information System and production activities in production planning and control.

H3: There is a relationship between Accounting Information System and production activities in production operations.

H4: There is a relationship between Accounting Information System and production activities in cost accounting.

\section{Analysis and Findings}

After highlighting the issues of this study and develop the hypotheses, in this section, this study exhibits the result of analysis as shown below. Before testing the research hypotheses, it is important that the data collected 
were checked for validity and reliability. The content validity of the instrument was ascertained by obtaining expert opinions from six lecturers in Jordanian universities. Additionally, it is necessary to rerun reliability test to check for the reliability of the survey instrument. According to Hair, Money, Samouel, and Page. (2007), the perfect measure of a concept needs more than one item. Moreover, according to Nunnally (1978), to assess the reliability of the survey instrument, the inter-item analysis can be used to test the scale's internal consistency. Hence, Cronbach's alpha is considered an adequate indicator of the internal consistency and the reliability of the survey instrument. The test shows that the Cronbach's alphas range from 0.708 to 0.754 , which exceed the minimum value of 0.7 to be acceptable (Sekaran \& Bougie, 2010). This means that the instruments used to measure the variable were acceptable and the data were later used for further analyses.

Out of 113 questionnaires distributed, only 72 were returned. Three of these questionnaires were excluded because they were invalid since some of them were incomplete or all answers were marked as "agree". The remaining 69 questionnaires yielded $61 \%$ responses rate.

The objectives of the current study are to examine the relationship between the accounting information system and production activities. These relationships are hypothesized as follows.

H1: There is a relationship between Accounting Information System and production activities in product design.

The result of simple regression between AIS and production design shows that the $\mathrm{r}$ value is $0.633(\mathrm{~F}=285.354$, Sig. $<0.001)$. This means that AIS is significantly and positively related to the production design, in which for one unit increase in the independent variable (AIS), the dependent variable (production design) will increase by $0.633(\mathrm{t}=5.984, \mathrm{p}=.000)$. Based on this result, the first hypothesis is supported.

$\mathrm{H} 2$ : There is a relationship between Accounting Information System and production activities in production planning and control.

The results of a simple regression between AIS and production planning and control shows that the $r$ value is $0.718(\mathrm{~F}=274.632, \mathrm{Sig} .<0.001)$. This means that AIS has a positive and significant relationship to production planning and control. The test also shows that for each unit increase in the AIS there is an expected increase in the dependent variable by $.718(\mathrm{t}=5.639, \mathrm{p}=0.000)$, suggesting that AIS predicts significantly the dependent variable. Hence, the second hypothesis is supported.

H3:There is a relationship between Accounting Information System and production activities in production operations

The test shows that the $\mathrm{r}$ value is $0.125(\mathrm{~F}=77.182$, Sig. $<0.001)$. This means that AIS has a positive and significant relationship to production operations. The test also shows that for each unit increase in the AIS there is an expected increase in production operations by $.125(\mathrm{t}=16.497, \mathrm{p}<0.01)$, suggesting that fair value predicts significantly the dependent variable. Hence, the third hypothesis is also supported.

H4: There is a relationship between Accounting Information System and production activities in cost accounting.

The result of simple regression between AIS and production activities in cost accounting shows that the $\mathrm{r}$ value is $0.289(\mathrm{~F}=10.766$, Sig. $=0.045)$. This means that there is a positive significant relationship between AIS accounting and production activities in cost accounting.. Hence, the fourth hypothesis is supported (Table 1).

Table 1. Simple regression summary

\begin{tabular}{llccccc}
\hline & N & Coefficient & $\boldsymbol{T}$ & p value & R & $\boldsymbol{F}$ value \\
\hline AIS with PD. & 69 & 0.870 & 5.984 & $0.000^{*}$ & 0.633 & 285.354 \\
AIS with PPC & 69 & 0.911 & 5.639 & $0.000^{*}$ & 0.718 & 274.632 \\
AIS with PO & 69 & 0.277 & 16.497 & $0.000^{*}$ & 0.125 & 77.182 \\
AIS with CA & 69 & 0.502 & 10.766 & $0.045^{* *}$ & 0.289 & 3.189 \\
\hline
\end{tabular}

Note. * Significant at $0.01 ; * *$ Significant at 0.05 .

\section{Discussion and Conclusion}

The results of current study came in line with the literature that examined the aforementioned relationships. For example Romney and Steinbart (2012) stated that Accounting Information System have a dynamic role in the production cycle. They added that these activities will enable companies to work with the information systems function to ensure that the AIS can provide the information needed to manage the four activities of the production cycle. 
Along with uniformity of the status of studied samples based on sample size through simple regression Test, the results show uniformity of studied samples concerning activities of product design and AIS and lack of uniformity in the status of programming activities and production operations. Lack of uniformity in programming activities and production operations indicates that the firms are not prepared to accept a modern costing system which indicates the significance of programming activities and production operations through compatibility of AISs in readiness of firms to accept modern costing systems.

This study recommends that the company have to concentrate on the application of accounting information system to benefit from its merits in all production activities. It will be helpful in future to explore the difficulties that face the Jordanian companies in applying accounting information system in production design.

\section{References}

Abernethy, M. A., \& Vagnoni, E. (2004). Power, organization design and managerial behaviour. Accounting, Organizations and Society, 29(3/4), 207-225. http://dx.doi.org/10.1016/S0361-3682(03)00049-7

Byrd, T. A., \& Turner, D. E. (2000). Measuring the flexibility of information technology infrastructure: Exploratory analysis of a construct. Journal of Management Information Systems, 17(1), 167-208.

Chapman, C. S., \& Kihn, L. A. (2009). Information system integration, enabling control and performance. Accounting Organizations and Society, 34(2), 151-169. http://dx.doi.org/10.1016/j.aos.2008.07.003

Chong, V. K., \& Chong, K. M. (1997). Strategic choices, environmental uncertainty and SBU performance: A note on the intervening role of management accounting systems. Account Business Resources, 27(4), 268276. http://dx.doi.org/10.1080/00014788.1997.9729553

Gul, F. A., \& Chia, Y. M. (1994). The effects of management accounting systems, perceived environmental uncertainty and decentralization on managerial performance: A test of three-way interaction. Accounting Organizations and Society, 19(4/5), 413-426. http://dx.doi.org/10.1016/0361-3682(94)90005-1

Hilton, R. W., Maher, M. W., \& Selto, F. H. (2000). Cost management: Strategies for business decision. New Jersey: McGraw Hill.

Institute of Management Accountants (IMA). (1995). Developing comprehensive performance indicators (p. 57). Statement no. 4U, March.

Ismail, N. A., \& King, M. (2005). Firm performance and AIS alignment in Malaysian SMEs. International Journal of Accounting Information Systems, 6, 241-259.

Jensen, M. C. (1983). Organization theory and methodology. Accounting Review, 53, 319-339.

Karthikeyan, M. (2010). Accounting information systems (1st ed.). Avinash Paperbacks.

Mia, L. (1993). The role of MAS information in organizations: An empirical study. The British Accounting Review, 25, 269-85. http://dx.doi.org/10.1006/bare.1993.1026

Morteza, R., \& Hossien, A. (2011). Assessment of internal factors effects on optimum application of production cycle Global. Journal of Management and Business Research, 11(7), 68-80.

Romeney, B., \& Steinbart, J. (2003). Accounting information systems (9th ed.). Prentice Hall Business Publishing.

Rushinek, A., \& Rushinek, S. F. (1995). Accounting software evaluation: Hardware, audit trails, backup, error recovery and security. Managerial Auditing Journal, 10(9), 29-37. http://dx.doi.org/10.1108/02686909510100887

Sajjadi, S. H., \& Tabatabaei, N. S. M. (2006). Accounting information systems. Charmin University, Ahvaz, Iran.

Simons, R. (1987). Accounting control systems and business strategy: An empirical analysis. Accounting, Organizations and Society, 12(4), 357-374. http://dx.doi.org/10.1016/0361-3682(87)90024-9

Zimmerman, J. L. (1995). Accounting for decision-making and control. Chicago: Irwin.

\section{Copyrights}

Copyright for this article is retained by the author(s), with first publication rights granted to the journal.

This is an open-access article distributed under the terms and conditions of the Creative Commons Attribution license (http://creativecommons.org/licenses/by/3.0/). 